\title{
Türkiye'deki Havayolu İşletmelerinin Hizmet Anlayışlarının Belirlenmesine Yönelik Bir Araştırma
}

\author{
A Research On The Determination Of Service Provisions Of Airport Operations In \\ Turkey
}

Nilüfer CANÖZ*

ÖZ

Günümüzde hızla büyüyen ulaşım sektörü ülkelerin ekonomik, sosyal ve kültürel olarak gelişsimine katkıda bulunan en önemli araçlardan birisidir. Deniz, Kara ve Hava taşımacıllğından oluşun ulaşım sektörü içerisinde ise; özellikle havayolu ulaşımı, hem ulusal hem de uluslararası ticareti arttırmakta, taşıma maliyetlerini düsürmekte, yolcuların veya eşyaların en kısa zamanda, en az maliyetle, en çok kapasite de ulaşımına olanak tanımaktadır. Bu imkânlarının yanında ayrlca, sosyal ve kültürel olarak da insanlar birbirine yaklaştırmakta ve kültürleri kaynaşstırmaktadır. Hava taşımacıllı̆ının dünyadaki bu etkileyici gelişmelerinden băğmsız kalamayan ülkemizde de son yıllarda hava taşımacılığı önemli mesafeler kat etmiştir. Hatta ülkemizdeki havayolu sektörü büyüme konusunda, dünya ortalamasının daha üstünde bir performans sergilemektedir. Ancak sektörde küreselleşmenin de etkisiyle rekabet çok yoğun yaşanmakta ve bu sektörde hizmet veren işletmeleri zor durumda birakmaktadır. Zorlu ortamdan çıkmanin yolu ise farkllaşsmaktan geçmektedir. Farklllaşma ise, hava yolu işletmelerinin sunmuş oldukları hizmetin kalitesinde, güvenlik anlayışında, ikramlarında veya yer hizmetlerinde kendisini göstermektedir. Ancak bu durumun gerçekten böyle olup olmadiğı ise araştırılması gereken bir durumdur. Bu amaçla, ülkemizde faaliyet gösteren yerli 9 havayolu işletmesinin Web siteleri, son görünür halleri ile içerik analizine tabi tutulmuştur. Web sayfaları üzerinden yapılan bu araştırmada, hava yolu işletmelerinin hizmet anlayışlarını kurumsal web sayfalarına yansıttıkları; hizmet anlaylşı çerçevesinde de en fazla hizmet sunumu, uçuş noktası çeşitliliği, güvenli ve zamanında uçuş hususlarında kendileriyle ilgili bilgilere yer verdikleri bulgularına ulaşılmıştır.

\section{ANAHTAR KELIMELER}

Hava Yolu, Hava Yolu İşletmeleri, Ulaştırma, Hizmet, Hizmet Anlayışı

\begin{abstract}
Today, the rapidly growing transport sector is one of the most important tools contributing to the economic, social and cultural development of countries. Sea, land and air transport in the transportation sector is comprised of; Especially airway transport, increases both national and international trade, reduces transportation costs and allows passengers or goods to travel at the shortest possible time, at the least cost, and at the most capacity. In addition to these possibilities, it also brings people closer to each other and cultures them socially and culturally. In recent years, air transportation has come to significant distances in our country which can not be independent of these impressive developments of air transport in the world. In fact, the airline sector in our country is performing above the world average in terms of growth. However, competition is intense due to the influence of globalization in the sector and enterprises that serve in this sector are in difficult situation. The way out of challenging environment is different. Differentiation is manifested in the quality of service provided by airline operators, in the sense of security, in catering or in ground handling services. However, whether this is really the case or not is a situation that needs to be investigated. For this purpose, Web sites of 9 domestic airline companies operating in our country have been subjected to content analysis with their last visible status. This survey, which is based on web pages, shows that airline operators are finding the best service delivery, variety of flight points, and positioning themselves on safe and timely flights.
\end{abstract}

\section{KEYWORDS}

Air Way, Airway Operations, Transportation, Service, Service Approach

\footnotetext{
Makale Gönderim Tarihi: 06/11/2017

* Yrd.Doç.Dr., Selçuk Üniversitesi Sivil Havacıllk Yüksekokulu, ncanoz@selcuk.edu.tr
}

Kabul Tarihi: 16/11/2017 


\section{GİRIŞ}

İnsanların veya eşyaların belirli bir noktadan diğer belirli bir noktaya yer değişimi olarak tanımlanan ulaşım, ülkelerin ekonomik, sosyal ve kültürel gelişimlerinde oldukça önemli bir yere sahiptir. Ekonomik açıdan üretici ve tüketicileri birbirine bağlamakta, ticaretin gelişimine katkıda bulunmakta, hız ve maliyet açısından ekonomiye fayda sağlamakta, istihdam kapasitesi yaratmaktadır. Sosyal açıdan, kentsel yaşam biçiminin oluşmasına, insanların daha iyi eğitim ve sağlık hizmetlerinden yararlanmasına, iş imkânlarının artmasına, daha yüksek gelir elde etmesine, yaşam biçiminin değişmesine, eğlence vb. hizmetlerden yararlanmasına neden olmaktadır. Kültürel açıdan ise, ulaşım sayesinde birbirine yakınlaşan insanların kültürel değerlerinin, gelenek ve göreneklerinin, dillerinin değişime uğramasına, çeşitlenmesine ve insanların kaynaşmasına neden olmaktadır.

Ülkelere ekonomik, sosyal ve kültürel açıdan bu katkıları sağlayan ulaşım sektörü deniz, kara, demir ve havayolu taşımacılığından oluşmaktadır. Özellikle havayolu taşımacılığı hız açısından, uzak mesafelerde maliyet açısından, zor coğrafi koşullarda ulaşıma en uygun araç olması açısından, diğer ulaşım araçlarına nazaran daha konforlu ve rahat kabul edilmesi açısından dolayı en gözde ulaşım sistemidir. Ancak bu avantajları yanında altyapı yatırımlarının yüksek olması, yakıt maliyetlerinin oldukça fazla olması, teknolojik gelişmelerin fazlaca yaşanması ve rekabetin yoğun olması gibi dezavantajları da içinde barındırmaktadır. Bütün bu dezavantajlarına rağmen günümüzde sağlamış olduğu hız, güvenlik, rahatlık ve geniş ulaşım ağ 1 sayesinde tercih edilme oranı gün geçtikçe de artmaktadır. Şöyle ki; 2003 yılında 34.443 yolcu hava yolu ulaşımını tercih ederken, 2016 yılında bu sayı 173.624 kişiye ulaşmışıı (www.shgm.gov.tr).

Hava taşımacılığının ülkemizdeki gelişimi ise 1911 yılına uzanmaktadır. İlk olarak 1911 yılında havadan insan taşımacılığına başlanan ülkemizdeki bu sektör 1980 y1lına kadar da devlet tekelindeydi. Ancak 1980 yılından sonra çıkarılan yasa ile özel havayolu işletmeleri de bu alana girmeye başlamışlardır. Özel hava yolu işletmelerinin sektöre girmeleri ise çetin rekabetin oluşmasını tetikleyen en önemli unsur olmuştur. $\mathrm{Bu}$ gelişmelere ek olarak bütün dünyayı etkisi altına alan küreselleşme neticesinde ortaya çıan serbestleşme çabaları, uluslararası havayolu işletmeleriyle yapılan işbirlikleri, ikili, üçlü anlaşmalar ve özelleştirme gibi düzenlemeler, ülkemiz havayolu işletmelerinin yoğun rekabet ortamında mücadele etmesini zorunlu kılan diğer etkileyici unsurlar olarak kendilerini göstermişlerdir.

Sadece ülkemizdeki değil tüm dünyadaki havayolu işletmeleri ile rekabet eden ülkemiz havayolu işletmelerinin hizmet sürecinde mücadele edebilmek adına farklılık yaratmaları ise zorunluluk olarak ortaya çıkmaktadır. Bu farklılıkları kimileri fiyat tarifesinde, kimileri yer hizmetlerinde, kimileri ikramlarında, kimileri güvenlik unsurlarında, kimileri ise hizmet kalitesinde göstermeye çalışmaktadır. Uyguladıkları farklı programları ya da anlayışları hedef kitlesine aktarabilmek için her türlü araçtan faydalanmakta ve bunu yansıtabilme çabası içerisine girmektedirler. Bu çalışmada farklılıkların ortaya konulup konulmadığını belirlemek açısından ülkemizde faaliyet gösteren 9 havayolu işletmesinin web siteleri içerik analizine tabi tutulmaktadır.

Havayolu işletmelerinin hizmet anlayışlarının web siteleri üzerinden analiz edilmesi amaçlanan bu çalışma iki bölümden oluşmaktadır. Literatür taraması ve içerik analizi yönteminin kullanıldığı bu çalışmanın birinci bölümünde, literatür taramasından elde edilen bilgilere yer verilmiş; ikinci bölümde ise Türkiye'de faaliyet gösteren havayolu işletmelerinin hizmet anlayışları web siteleri üzerinden içerik analizi yolu ile ortaya konulmaya çalışılmıştır.

\section{HAVAYOLU IŞSLTMELERINNDE HIZMET}

Fiziksel olmayan bir ürün olarak kabul edilen hizmet, bir ücret ve menfaat karş1llı̆ı üretilmekte olup, stoklanamama, depolanamama, eş zamanlılık gerektiren, verenle alanın etkileşim içinde olduğu ve anında tüketilme özelliklerine sahiptir (Canöz 2015:71). İnsanların, yükün, postanın, yer ve zaman faydası sağlayacak şekilde bir hava aracı ile havadan yer değiştirmesi olarak tanımlanan havayolu taşımacılığı da çeşitli hizmetlerden oluşan bir süreçtir. Bunlar; uçak bakım, tamir, onarım, yer hizmetleri, ikram ile ilgili hizmetler, güvenlik hizmetleri, rezervasyon vb. hizmetleri kapsamaktadır (Gerede 2015:3).

Havayolu taşımacılığ hizmetleri uçuş öncesi, uçuş sırası ve uçuş sonrası olmak üzere üç bölümden oluşmaktadır. Uçuş öncesi; müşterinin havayolu hizmetiyle ilgili bilgi talep etmesiyle başlamakta, satın alma kararını vermesi, ödemeyi yapması ve bileti satın almasıyla devam etmektedir. Daha sonra müşterinin havaalanına gelmesi, havaalanı işletmesinden hizmeti alması, bagaj ve bilet işlemlerini tamamlaması, güvenlik, pasaport ve gümrük işlemleri ve sonrasında uçağa binmesi ile sona erer. Uçuş sırasında ise; kabin hizmeti alması, uçuş sonrasında ise; uçaktan ayrılıp, bagajlarını alması ve en sonunda havaalanından ayrılması ile hizmet tamamlanmaktadır (Gerede 2015:10). 
Havayolu işletmelerinin vermiş oldukları bu hizmetlerin kendine has özellikleri bulunmaktadır. Bunlar; talep dalgalanmalarına karşı depolanamaması, genellikle kişiselleştirilmeleri, diğer ürünlerin satışında olduğu gibi, bu hizmetlerin değiştirilmesi veya iade edilememeleri, satışlarından önce kalitesinin kontrol edilmemesi veya hizmeti satın almadan önce test edilmemesi, mekanik sorunlar veya hava durumunun ön görülemezliği nedeniyle hizmetin teslimatı her zaman garanti edilememesi, bireysel olarak değil gruplar halinde üretilmesi gibi özelliklerdir (Wensveen 2007:261-262). Bu özellikler ise havayolu hizmeti sunan işletmeleri ve bu hizmeti alacak müşterileri zor duruma sokmaktadır. Müşteriler bu belirsizlik altında işletmeyi tercih etme ve değerlendirme konusunda zorlanmakta; hizmeti sunan işletmeler de, hizmetlerini pazarlayabilmek, rekabet ortamında mücadele edebilmek adına bu elle tutulamayan unsurları somutlaştıracak stratejiler arama çabasına girmektedirler.

Havayolu işletmelerince sunulan hizmetler ya da hizmet anlayışları uygulanan havayolu taşımacıllı̆ı modeline göre de şekillenebilmektedir. Geniş coğrafi bir alanda, genellikle merkez-uydu ağ yapılanması ile farklı sınıflarda hizmet sunan, karmaşık hizmet tasarımlarına sahip olan, bağlantılı ve uzun uçuşlar, büyük ve karmaşık filo yapısı, karmaşık hizmet süreçleri, karmaşık planlama ve operasyonel sistemleri gerektiren, birbirinden farklı büyüklükte ve tipte uçaklarıyla faaliyette bulunan geleneksel havayolu taşımacılığı modelini uygulayan işletmelerde, full hizmet, hizmet kalitesi anlayışı geçerliyken; geleneksel havayolu işletmelerinin benimsediği bazı hizmetlerden (ikramsız, düşük düzeyde ya da ücretli ikram konsepti; doğrudan dağıtım kanallarına yoğunlaşma; noktadan noktaya ve nispeten kısa hat seçimi; tek tip filo kullanımı ve yoğun birincil havaalanları yerine ikincil havaalanlarının seçilmesi vb.) vazgeçerek maliyetlerini azaltan, buna bağlı olarak da ucuz fiyatla hizmet sunan düşük maliyetli havayolu taşımacıllğı modelini tercih eden işletmelerde ise, ucuz bilet anlayışı ön plana çıkarılmaktadır. Tarifesiz (charter) havayolları modelinde ise genellikle doğrudan herhangi bir hizmet anlayışı söz konusu olmayıp, tur acentelerine uçaktaki koltukların hepsinin veya bir bölümünün blok satışı şeklinde satılması ya da kiralanması söz konusu olmaktadır (Şengür ve Şengür 2012:32).

İşletmeler tarafindan uygulanan modeller farklı olsa da havayolu müşterilerinin, seyahat kararlarını vermede havayolları arasında seçim yaparken verilen hizmetlerin beş özelliğinin dikkate alındığı da bir gerçektir. Bunlar (Doganis 1991:245);

-Fiyatlar ve fiyat koşulları,

-Sunulan hizmetlerin zamanlamaya dayalı özellikleri yani tarife ile ilgili özellikler,

-Konfor ile ilgili özellikler,

-Bir havayolu işletmesinin hizmetlerine erişim kolaylığg ve rahatlığı,

-Havayolu işletmesinin kendisi veya verdiği hizmetle ilgili imajıdır.

Fiyatlar ve Fiyat Koşulları: Fiyatlar tüketicilerin tercihinde rol oynayan en önemli faktörlerden birisidir. Fiyatlar pek çok faktöre bağlı olarak değişiklik göstermektedir. Uçağın büyüklüğü, tipi, doluluk oranı, güzergâhtaki trafik durumu, seferlerin uzun ya da kısa olması, seferlerin yoğunluğu, yakıt giderleri, bakım giderleri, personel giderleri gibi maliyetler, uçuşa olan talep, rakip firmaların belirlediği fiyatlar, uçuş sezonu, tatil günleri v.b faktörler fiyat belirlenmesinde oldukça etkilidir. Fiyat müşteriye göre de değişiklik gösterebilmekte, uçak içerisinde first class, business class ya da economi class uygulamasına veya iş amaçlı veya tatil amaçlı geziye çıkanlara göre değişebilmektedir. Havayolu işletmelerinin uyguladığı havayolu modeli de (geleneksel, düşük maliyetli, charter ya da bölgesel havayolu modeli) fiyatların belirlemesinde etkindir.

Sunulan hizmetlerin zamanlamaya dayalı özellikleri yani tarife ile ilgili özellikler: Tarifeye bağlı özellikler yaygın uçuş ağı, uçuş sıklığı, filonun durumu, uçuş planları, direk uçuşun olup olmadığı, seyahatin süresi gibi hizmet unsurları havayolu müşterilerinin karar verme aşamasında önemli faktörlerden bazılarıdır.

Konfor ile ilgili özellikler: Kabin içi hizmetler, ikram çeşitliliği, ikram kalitesi, ikramların ücretli olup olmaması, koltukların konforu, genişliği, koltuk arası mesafe ya da uçak içi eğlence çeşitliliği konforu belirleyen unsurlardır.

Bir havayolu işletmesinin hizmetlerine erişim kolaylığı ve rahatlığı: Müşteriler, rahat, hızlı ve güvenilir şekilde biletleme, check-1n ve rezervasyon işlemini yapabiliyorsa, bagaj işlemlerini kolayca gerçekleştirebiliyorsa, uçuş ile ilgili sorunlarda personel samimi bir şekilde hızla çözüm buluyorsa, sık uçan yolcular için ayrıcalıklar tanınıyorsa karar verme süreci hızlanabilmektedir.

Havayolu işletmesinin kendisi veya verdiği hizmetle ilgili imajı: Kurumla ilgili müşterilerinin zihninde oluşan algılar bütünü olarak tanımlanan imaj, kuruma rekabette uzun süre kalabilme, herhangi bir olumsuz durumda sigorta, en iyi nitelikteki personeli bünyesine katabilme, pazarlamada daha etkili olabilme, maliyetleri azaltabilme ve stratejik yön tayinine katkıda bulunma gibi pek çok artı sağlamaktadır (Steıl ve Emery 1997:9). Kurumun imajını belirleyen görsel kimlik unsurlarından olan logo, kullanılan renkler, satış ofislerinin dizaynı, uçak içi dizaynı, uçak içi yerleşim şekli, bekleme salonları, personel kıyafetleri, kurumun 
yapmış olduğu sosyal sorumluluk faaliyetleri, halkla ilişkiler çalışmaları, medya ile ilişkileri, sponsorlukları ve hizmet kalitesi gibi etkili faktörler bunlardan bazılarıdır.

Sektördeki yoğun rekabette havayolu işletmeleri için sadece fiyatı düşürmek ya da sadece konfor ile ilgili bileşenleri öne çıkarmak veya bir etkinliğe sponsor olmak tek başına yeterli olmamaktadır. Havayolu ulaşımında genellikle verilen hizmetler, uçulan uçaklar, uçak içi teknolojiler birbirine oldukça yakındır. $\mathrm{Bu}$ nedenle işletmeler farklı yollar aramaktadır. Bunlardan biriside müşterilerle karşılıklı etkileşime geçmek, onlara kendisi ve hizmetleri hakkında bilgi vermek, onları vermiş oldukları hizmetlerin farklılığ 1 konusunda ikna etmek için interneti kullanmasıdır. Özellikle de günümüzde en güçlü tanıtım araçlardan birisi kabul edilen web siteleri aracılığıyla kendilerini ve hizmetlerini tanıtmaktadırlar.

Web siteleri, günümüzde işletmelerin dış dünyaya açılan penceresi olarak kabul edilmektedir (Sayımer 2008:88). Onlar, önemli bir bilgi kaynakları, ürün ve hizmetler hakkında eksiksiz bilgi ve arama motorları gibi araçlarla bilgiye hızlı erişim sağlayıcılarıdır. Müşterilerin işletmelerle sorun yaşaması durumunda, müşteri hizmetleri, kişiselleştirme ve iletişim kolaylığı da dahil olmak üzere, uygun düzeyde hizmet etkileşimi talep edebildikleri, müşterilerin "güvenini" geliştirmek için gizlilik uygulamalarını benimseyen, interaktif iletişim ortamlarıdır (X1e and Barnes 2009:52).

\section{HAVAYOLU ISSLETMELERININ WEB SITELERINDE HIZMET}

Günümüzde işletmeler internetin sağladığı kolaylıkları ve iletişim gücünü etkin biçimde kullanmaya başlamışlardır. Web siteleri de bu kolaylıklardan birisidir. Web sitelerini; hedef kitlelerine bilgi sunmak, onlarla ilgili bilgi toplamak, rakipleriyle rekabet edebilmek, kurum imajını geliştirmek, kurum kimliğini pekiştirmek, itibarını güçlendirmek, çalışanlarıyla iletişime geçebilmek, herkese ulaşabilmek, mal/hizmetleriyle ilgili satış yapabilmek ve yine hizmet sunumlarıyla ilgili detaylı bilgi verebilmek için tasarlayıp, geliştirmektedir.

Havayolu işletmeleri de bu amaçlar doğrultusunda, web siteleri aracıllğıyla müşterilerine online bilet satış1, rezervasyon, check-1n, otel, kiralık araç vb. ek hizmetler, bagaj takibi, yemek seçimi, koltuk tercihi, uçuş paketleri, uçuş planları, özel yolcu hizmetleri, tarife, uçuş noktaları, uçuş ağı, filosu vb. bilgiler, iniş-kalkış saatleri, yolcu programları, online anket, dergi, bülten gibi hizmetler sunmaktadır.

Web siteleri aracılığıyla verilen bu hizmetler hem işletmeler açısından hem de müşteri açısından oldukça avantajlı olabilmektedir. Şöyle ki; işletmeler on-line bilet satışı ve rezervasyon gibi hizmetleri web sitesi aracılığıyla daha kolay, daha az maliyetle ve zaman sıkıntısı olmadan verebilmekte, aynı şekilde müşteriler de bu hizmetler sayesinde para, zaman ve enerji tasarrufu sağlayabilmektedirler. Yine aynı şekilde işletmeler tarafindan sunulan yemek seçimi, koltuk seçimi gibi hizmetler, müşterilerin tercihlerine bırakılarak, onların istek ve beklentileri dikkate alınmakta ve onların daha rahat yolculuk yapmaları sağlanabilmektedir. Uygulanan yolcu programları da işletme-müşteri ilişkisi açısından oldukça önemlidir. Bu programlar sayesinde işletmeler müşterileriyle uzun dönemli ilişki kurabilmekte ve onları sadık müşteri haline getirebilmekte, müşteriler ise indirimli bilet, fazla bagaj hakkı, hızlı rezervasyon, özel salonları kullanma imkanı gibi hizmetlerden yararlanabilmektedir.

İşletmeler benimsedikleri hizmet anlayışlarını sundukları her hizmete yansıtmaktadırlar. Havayolu işletmelerinin birbirine benzer hizmet sunumunda farklılaşmak ve tercih edilebilir olmak için fiyat, tarife, konfor, hizmetlere erişim kolaylığı ve rahatlığı ile imaj önemli faktörlerdir (Doganis 1991:245).

\section{YÖNTEM}

Ülkemizde faaliyette bulunan havayolu işletmelerinin hizmet anlayışlarının web sitesi üzerinden belirlenmesini amaçlayan bu çalışmada; Sivil Havacılık Genel Müdürlüğü tarafından ruhsatlandırılan tarifeli ve tarifesiz olmak üzere 13 havayolu işletmesi değerlendirmeye alınmış; ancak yapılan inceleme sonucunda bu havayollarından yük taşımacılığı yapan 3 adet işletme ile bölgesel taşımacılık yapan 1 adet işletme araştırma kapsamı dışında tutulmuşlardır. Bu ayrıştırmadan sonra 9 havayolu işletmesi bu çalışmanın araştırma evrenini oluşturmuştur.

Araştırmada yöntem olarak, literatür taraması ve nitel araştırma yöntemlerinden biri olan içerik analizi yöntemi kullanılmıştır. İçerik analizi, belli bir metnin, kitabın, belgenin belli özelliklerini sayılaştırarak belirleme amacı ile yapılan bir taramadır. Belgelerdeki bakış açıları, felsefeler, dil, anlatım vb. özellikler derinliğine ve belli ölçütlere göre yapılacak çözümlemelerle anlaşılabilmektedir (Karasar 2010:184). Çalışmada havayolu işletmelerinin ücret, tarife, konfor, hizmetlere erişim kolaylığı ve imaj olarak görülen hizmet bileşenleri çerçevesinde içerik analizine tabi tutulmaktadır.

Yoğun rekabet ortamı içerisinde faaliyette bulunan havayolu işletmelerinin rekabette üstünlük sağlayabilmek amacıyla ön plana çıkardıkları hizmet anlayışlarının, web siteleri üzerinden ortaya konulup 
konulmadığ ise, araştırılması gereken bir durumdur. Bu alanda yapılmış çalışmaların kıtlığı ve hava yolları işletmelerinin hizmet anlayışlarının web sayfaları üzerinden ortaya konulmaya çalışılması ise çalışmayı önemli kılmaktadır.

\section{BULGULAR}

\subsection{Havayolu İşletmeleri ve Büyüklükleri}

Türkiye'de aktif olarak faaliyette bulunan ve araştırmamıza konu olan hava yolu işletmeleri, Devlet Hava Meydanları İşletmeleri (DHMI) 2016 Yılı Faaliyet Raporuna göre filo ve yolcu trafiği açısından değerlendirildiğinde ilk sırayı “THY A.O.”nın aldığı görülmektedir (Bkz. Tablo 1). Ondan sonra ise sırasıyla; Pegasus Hava Taşımacılık A.Ş., Güneş Ekspres Havacılık A.Ş., Onur Aır Taşımacılık A.Ş., Atlasjet Havacılık A.Ş., Hürkuş Havayolu Taşımacılık A.Ş., İHY İzmir Havayolları A.Ş., Tailwind Havayolları A.Ş. ve Turistik Hava Taşımacılık A.Ş. gelmektedir.

Tablo 1: Hava yolu işletmelerinin filo ve yolcu sayısı bakımından büyüklükleri

\begin{tabular}{|c|c|c|c|c|}
\hline SIRA & İŞLETME & FİLOSU & $\begin{array}{l}\text { İÇ HAT YOLCU } \\
\text { TRAFIĞĞ }(\%)\end{array}$ & $\begin{array}{c}\text { DIŞ HAT } \\
\text { YOLCU } \\
\text { TRAFIĞİ (\%) }\end{array}$ \\
\hline 1 & THY A.O. & 300 & 54.0 & 66.4 \\
\hline 2 & Pegasus Hava Taşımacılık A.Ş. & 70 & 29.9 & 15.3 \\
\hline 3 & Güneş Ekspres Havacılık A.Ş. & 49 & 5.0 & 7.0 \\
\hline 4 & Onur Air Taşımacılık A.Ş. & 25 & 6.0 & 3.1 \\
\hline 5 & Atlasjet Havacılık A.Ş. & 25 & 3.5 & 3.8 \\
\hline 6 & Hürkuş Havayolu Taşımacılık A.Ş. & 8 & 0.0 & 1.0 \\
\hline 7 & İzmir Havayolları A.Ş. (İzair) & 8 & 0.0 & 0.0 \\
\hline 8 & Tailwind Havayolları A.Ş. & 5 & 0.0 & 0.7 \\
\hline 9 & Turistik Hava Taşımacılık A.Ş. & 11 & 0.0 & 2.3 \\
\hline 10 & Diğer Hava Yolu İșletmeleri & - & 1.6 & 0.4 \\
\hline
\end{tabular}

Kaynak: 2016 y1lı DHMİ Faaliyet Raporu

Türk Hava Yolları, sahip olduğu 300 adetlik uçak sayısı ve taşıdığ1 \%54.0 iç hat, \%66.4 dış hat yolcu trafiğiyle en yakın rakibini dörde katlayarak 2016 yılı verilerinde ilk sırada yer almaktadır. İlk uçuşuna 1933 yılında başlayan THY, müşterilerine sağladığı geniş uçuş ağı, yüksek hizmet kalitesi, güçlü filosu, dünyanın en fazla diş hat noktasına uçan, pek çok ödüle layık gösterilen, müşteri memnuniyetinin, verilen hizmetin her aşamasında olması gerektiğini savunan, uçuş öncesi ve uçuş boyunca farklı alternatifler sunan, farklı konseptteki servisleriyle, uçak içi eğlence seçenekleriyle, kişiye özel sürpriz özel gün kutlamalarıyla, ev konforu sunan uyku seti gibi ekstra hizmetleriyle; yolcularına uçuş deneyimlerinin her aşamasından memnun kalacakları bir hizmet sunmayı hedeflemektedir (THY 2016 Y1llk Raporu). "www.turkishairlines.com" adresli kurumsal web sitesinde "Uçak bileti fiyatları THY kalitesiyle" sloganıyla hizmetini sürdürmektedir.

1990 yılında charter uçuşlarla havacılık sektörüne giriş yapmış "Pegasus" firması ise, yine yukarıdaki Tablo 1 'in verilerine göre uçak sayısı ve yolcu trafiğiyle ikinci sırada yer almaktadır. 2005 yılından günümüze kadar iş modelini, "düşük maliyetli ağ taşıyıcısı" olarak değiştirerek; "düşük fiyatlı ve zamanında kalkış performansı yüksek", hizmet sunumuna odaklamıştır. "www.flypgs.com" adresli kurumsal web sitesinde "Ucuz uçak bileti demek özgürlük demek" sloganıyla hizmet vermektedir.

Ülkemizdeki hava yolu işletmeleri sıralamasında sahip olduğu 49 adet uçağı, $\% 5.0$ iç hat ve $\% 7.0$ diş hat yolcu taşıma oranıyla üçüncü sırada bulunan "Güneş Ekspress A.Ş.” ya da diğer ismiyle "SunExpress"; Türk Hava Yolları ve Lufthansa'nın eşit ortaklığında 1989 yılında kurulmuştur. Almanya başta olmak üzere, uzun süre Avrupa ile Antalya arasında turistik charter seferleri düzenlemiş, 2001 yılında başlattığ 1 AntalyaFrankfurt uçuşlarıyla, Türkiye'nin yurtdışına tarifeli sefer düzenleyen ilk özel havayolu olmuştur. Kendisini hem fiyat hem kalite de, en iyi değerde hizmet veren tatil havayolu olarak gören işletme, düşük fiyat anlayışına sahiptir. "www.sunexpress.com" adresli kurumsal web sitesinde "Ucuz uçak bileti" sloganıyla hizmet vermektedir.

Onur Air Taşımacılık A.Ş. 1992 yılında kurulmuş olup, 2016 verilerine göre 25 adet uçağa, $\% 6.0$ iç hat yolcu taşıma oranına ve \%3.1 dış hat yolcu taşıma oranına sahip dördüncü sıradaki hava yolu firması durumundadır. Onur Air, düşük maliyetli hava taşımacılığına yönelik, tarifeli/tarifesiz uçuşlar düzenlemektedir. "www.onurair.com" adresli kurumsal web sitesinde "En uygun fiyata uçak bileti" sloganıyla hizmet vermektedir. 
Atlasglobal, 2001 yılında "Tarifesiz İç Hat ve Dış Hat Uçuşlarda Yolcu ve Kargo Taşımacılı̆̆ı" gerçekleştirmek üzere kurulmuştur. İç ve dış hat tarifeli uçuşlarına 2004 yılında başlamıştır. 2015 yılına kadar "Atlasjet" olarak kullandığı ismini "Atlasglobal” olarak değiştirmiştir. Günümüzde sahip olduğu 25 adetlik uçak sayıs1, \%3.5 iç hat ve \%3.8 dış hat yolcu taşıma oranıyla beşinci sırada yer almaktadır. "www.atlasglb.com" adresli kurumsal web sitesinde "En uygun yurtiçi, yurtdışı uçak bileti" sloganıyla hizmet vermektedir.

"Hürkuş Havayolu" ya da diğer ifadesiyle "Freebird", Haziran 2000 yılında kurulmuş ve 2001 y1lında uçuşa başlamış uluslararası bir charter havayolu şirketidir. Filosunda bulunan 8 adet uçağı ve $\% 1.0$ diş hat yolcu taşıma oranıyla ülkemizin havayolu taşımacılığında altıncı sırada yer almaktadır. Günümüzde halen Avrupa ve Ortadoğu'da operasyonlarına devam etmektedir. "www.freebirdairlines.com" adresli kurumsal web sitesinde hizmet vermektedir.

2005 yılında kurulan "İzair" firması, 2006 yılında “Tarifesiz Yük ve Yolcu Taşımacılığı Ruhsatı" almış ve Pegasus Havayolları ile İşbirliği Sözleşmesi imzalamıştır. Yine aynı yıl Pegasus Havayolları adına uçuşlarına başlamıştır. 2010 yılında Pegasus Havayolları, İzair'in \%72,57'sini satın almıştır. 2011 yılında iş modeli değiştirilerek wet-lease operasyon tipine geçilerek, uçaklar Pegasus Havayolları'na kiralanmıştır, filosunda toplam 8 adet uçağı vardır ve ülkemiz havayolu taşımacılığında yedinci sırada bulunmaktadır. "www.izair.com.tr" adresli kurumsal web sitesinden hizmet vermekte, ancak uçuşlarla ilgili olarak bilgi alınmak istenmesi durumunda "www.flypgs.com" kurumsal web sitesine yönlendirme yapılmaktadır.

2006 yılında kurulan Türk ve İngiliz ortaklığı olan "Tailwind Havayolları"; Turistik Charter Uçuş olan, yerli ve yabancı tüm seyahat acenteleri ve tur operatörlerinin sezonluk veya belli bir dönemi kapsayan uçuşlarında uçak ihtiyaçlarını karşılamak, firma, kurum ve spor kulüplerinin ihtiyaç duydukları münferit uçak kiralamalarında yardımcı olmak, uçak ihtiyacı olan yerli ve yabancı havayollarına uçuş ekibi ile birlikte uçak kiralamak gibi hizmetler sunmaktadır. Filosunda toplam 5 adet uçağı vardır ve dış hat yolcu taşımanın \%0.7'sine hizmet vermektedir; sahip olduğu özellikler nedeniyle de ülkemiz havayolu taşımacılığında sekizinci sirada bulunmaktadır. "www.tailwind.com.tr" adresli kurumsal web sitesinde hizmet vermektedir.

"Turistik Hava Taşımacılık A.Ş." unvanıyla hizmet sunan "Corendon Airlines", 2005 yılında uçuşlarına başlamış ve ilk uçuşunu Türkiye-Amsterdam olarak gerçekleştirmiştir. Filosunda toplam 11 adet uçağı vardır. Türkiye'deki dış hat havayolu taşımacılığının \%2.3'ünü kullanan “Turistik Hava Taşımacılık A.Ş.” (Corendon Airlines), havayolları siralamasında dokuzuncu sirada yer almaktadır. "www.corendonairlines.com" adresli kurumsal web sitesinde "Ucuz uçak bileti" sloganıyla hizmet vermektedir.

Türkiye'de hava yolu taşımacılığı yapan ama daha önce belirtilen nedenlerle çalışmaya dahil edilmeyen diğer hava yolu işletmeleri \% 1.6 iç hat, \%0.4 diş hat oranlarıyla onuncu sırada yer almaktadırlar.

Yukarıda ayrıntılı olarak ele alınan DHMI'nin 2016 yılı Faaliyet Raporu verileri 1şığında toplamda 501 uçaktan oluşan Türkiye'nin hava yolu taşımacılığı filosu içerisinde en fazla pay \%54.0'lük iç hat oranıyla ve \%66.4'lük dış hat oranıyla THY'ye aittir. Dolayısıyla hem iç hatta hem de dış hatta Türkiye'nin hava yolu taşımacılığının dinamosunu THY'nin oluşturduğu görülmektedir.

\subsection{Hava Yolu İşletmelerinin Hizmet Anlayışlarının Analizi}

Türkiye'de faaliyette bulunan ve araştırmamıza konu olan dokuz hava yolu şirketinin hizmet anlayışlarının web sitelerine yansıtılmasını incelemiş olduğumuz çalışma, beş hizmet bileşeninden oluşmaktadır. Bunlar; ücret, tarife, konfor, hizmetlere erişim kolaylığı ve imaj bileşenleri şeklinde sıralanabilmektedir.

\subsection{1.Ücret Bileşeni Analizi}

Hizmet bileşenlerinden ücret bileşeni düşük fiyat-ucuz bilet, fiyat+hizmet-normal bilet, promosyon uçak biletleri ve uçuş paketleri verilerinden oluşmaktadır. Havayolu işletmeleri bu veriler doğrultusunda incelendiğinde aşağıdaki tablo (Tablo 2) ortaya çıkmaktadır. 
Tablo 2: Hava yolu işletmelerinin ücret bileşeni verileri

\begin{tabular}{|l|l|l|l|l|l|l|l|l|l|}
\hline \multicolumn{1}{|l|}{} & & & \\
\hline
\end{tabular}

Ücret Bileşeni verilerine bakıldığında; THY'nin web sitesinde ücret bileşenlerinden düşük fiyat-ucuz bilet ve uçuş paketleri bilgilerine yer vermediği; fiyat+hizmet-normal bilet ve promosyon uçak biletleri bilgilerine yer verdiği;

Pegasus'un kurumsal web sayfasında ücret bileşenlerinden "fiyat+hizmet-normal bilet" bilgisine yer vermediği; düşük fiyat-ucuz bilet, promosyon uçak biletleri ve uçuş paketleri bilgilerine yer verdiği;

Güneş (Sun) Ekspres'in kurumsal web sayfasında ücret bileșenlerinden "fiyat+hizmet-normal bilet" bilgisine yer vermediği; düşük fiyat-ucuz bilet, promosyon uçak biletleri ve uçuş paketleri bilgilerine yer verdiği;

Onur Air'in kurumsal web sayfasında ücret bileşenlerinden "fiyat+hizmet-normal bilet" bilgisine yer vermediği; düşük fiyat-ucuz bilet, promosyon uçak biletleri ve uçuş paketleri bilgilerine yer verdiği;

Atlasjet'in kurumsal web sayfasında ücret bileşenlerinden düşük fiyat-ucuz bilet, fiyat+hizmet-normal bilet, promosyon uçak biletleri ve uçuş paketleri bilgilerinin tamamına yer verdiği;

Hürkuş, İzair ve Tailwind'in kurumsal web sitelerinde ücret bileșenlerine yer vermediği;

Turistik Hava Taşımacılık'ın kurumsal web sayfasında ücret bileşenlerinden düşük fiyat-ucuz bilet ve uçuş paketleri bilgilerine yer verdiği görülmektedir.

Sonuç olarak THY normal bilet ile vermiş olduğu hizmetlerden ek ücret almadığı anlayışını yansıtırken; Pegasus, Güneş (Sun) Ekspres, Onur Air, , AtlasJet ve Turistik Hava Taşımacılık işletmeleri düşük fiyat-ucuz bilet bileşeni ile fiyatlarının ucuz olduğu anlayışını yansıtmaktadır.

\subsubsection{Tarife Bileşeni Analizi}

Hizmet bileşenlerinden tarife bileşeni yeterli uçuş sıklığı, yaygın uçuş ağ süresi, uygun uçuş planı, direkt uçuş ve uçuş noktaları verilerinden oluşmaktadır. Havayolu işletmeleri bu veriler doğrultusunda incelendiğinde aşağıdaki tablo (Tablo 3) ortaya çıkmaktadır.

Tablo 3: Hava yolu işletmelerinin tarife bileşeni verileri

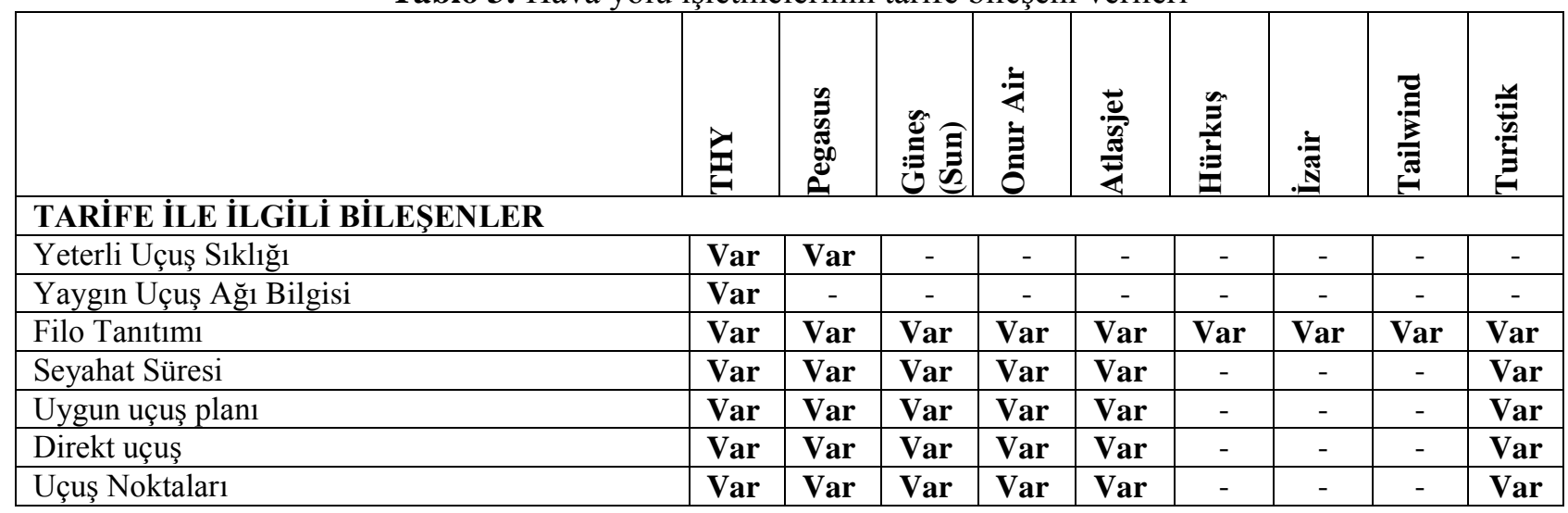

Tarife Bileşeni verilerine bakıldığında; THY'nin yeterli uçuş sıklığı, yaygın uçuş ağı bilgisi, filo tanıtımı, seyahat süresi, uygun uçuş planı, direkt uçuş ve uçuş noktaları bilgilerinden oluşan Tarife ile İlgili Bileşenlerin hepsine yer verdiği;

Pegasus'un Tarife ile İlgili Bileşenlerden yaygın uçuş ağı bilgisine yer vermediği; yeterli uçuş sıklığı, filo tanıtımı, seyahat süresi, uygun uçuş planı, direkt uçuş ve uçuş noktaları bilgilerine yer verdiği; 
Güneş (Sun) Ekspres'in Tarife ile İlgili Bileşenlerden yeterli uçuş sıklığı ve yaygın uçuş ağı bilgilerine yer vermediği; filo tanıtımı, seyahat süresi, uygun uçuş planı, direkt uçuş ve uçuş noktaları bilgilerine yer verdiği;

Onur Air'in Tarife ile İlgili Bileșenlerden yeterli uçuş sıklığı ve yaygın uçuş ağı bilgilerine yer vermediği; filo tanıtımı, seyahat süresi, uygun uçuş planı, direkt uçuş ve uçuş noktaları bilgilerinden oluşan bilgilere yer verdiği;

Atlasjet' in Tarife ile İlgili Bileşenlerden yeterli uçuş sıklığı ve yaygın uçuş ağı bilgilerine yer vermediği; filo tanıtımı, seyahat süresi, uygun uçuş planı, direkt uçuş ve uçuş noktaları bilgilerinden oluşan bilgilere yer verdiği;

Hürkuş, İzair ve Tailwind'in kurumsal web sitelerinde Tarife ile İlgili Bileşenlerden sadece filo tanıtımına yer verdiği;

Turistik Hava Taşımacılık'ın Tarife ile İlgili Bileşenlerden filo tanıtımı, seyahat süresi, uygun uçuş planı, direkt uçuş ve uçuş noktaları bilgilerine yer verdiği görülmektedir.

Bu verilere göre havayolu işletmelerinin çoğunun tarife ile ilgili bileşenlere önem verdiği, THY'nin "yaygın uçuş ağı" ile farklılık gösterdiği ortaya çıkmaktadır.

\subsubsection{Konfor Bileşeni Analizi}

Hizmet bileşenlerinden konfor bileşeni sınıflandırma-economy/comfort/business, özel yolcu hizmetleri, koltuklar arası mesafe, koltuk konforu, ücretsiz tercihli koltuk seçimi, ücretli tercihli koltuk seçimi, kabin içi hizmet, ücretsiz yemek servisi, ikram çeşitliliği (tazeliği, miktarı, görüntü v.b), müşteriye özel yemek çeşitleri (vejeteryan, diyabetik vb.), ek ücretli ikramlar, kabin görevlilerinin sayısı, uçak içi eğlence hizmetleri (kitap, dergi, gazete, film gibi), uçakta satış (kozmetik, parfüm, takı, aksesuar vb.) verilerinden oluşmaktadır. Havayolu işletmeleri bu veriler doğrultusunda incelendiğinde aşağıdaki tablo (Tablo 4) ortaya çıkmaktadır.

Tablo 4: Hava yolu işletmelerinin konfor bileşeni verileri

\begin{tabular}{|c|c|c|c|c|c|c|c|c|c|}
\hline & 胥 & 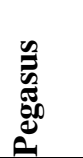 & 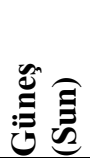 & $\begin{array}{l}\vdots \\
\vdots \\
\vdots \\
\Xi\end{array}$ & 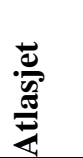 & 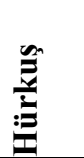 & : & 氞 & 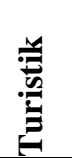 \\
\hline \multicolumn{10}{|l|}{ KONFOR İLE İLGİLİ BİLEŞENLER } \\
\hline Sinıflandırma-Economy/Comfort/Business & Var & - & - & - & Var & - & - & - & - \\
\hline Özel yolcu Hizmetleri & Var & Var & Var & Var & Var & - & - & Var & Var \\
\hline Koltuklar arası mesafe & - & Var & Var & - & Var & - & - & - & - \\
\hline Koltuk konforu & - & - & - & - & - & - & - & - & - \\
\hline Ücretsiz Tercihli koltuk seçimi & Var & - & - & - & - & - & - & - & - \\
\hline Ücretli Tercihli koltuk seçimi & Var & Var & Var & Var & - & Var & - & - & Var \\
\hline Kabin İçi Hizmet & Var & - & - & - & Var & - & - & - & - \\
\hline Ücretsiz Yemek servisi & Var & - & - & - & Var & - & - & - & - \\
\hline İkram çeşitliliği (tazeliği, miktarı, görüntü v.b) & Var & Var & - & - & - & - & - & - & - \\
\hline $\begin{array}{l}\text { Müşteriye özel Yemek çeşitleri (Vejeteryan, } \\
\text { diyabetik vb.) }\end{array}$ & Var & Var & Var & - & Var & Var & - & Var & - \\
\hline Ek Ücretli ikramlar & - & Var & Var & Var & Var & - & - & Var & Var \\
\hline Kabin görevlilerinin sayısı & - & - & - & - & - & - & - & - & - \\
\hline $\begin{array}{l}\text { Uçak içi eğlence hizmetleri (kitap, dergi, gazete, } \\
\text { film gibi) }\end{array}$ & Var & - & Var & - & - & - & - & - & - \\
\hline $\begin{array}{l}\text { Uçakta Satı̧̧ (Kozmetik, parfüm, takı, aksesuar } \\
\text { vb.) }\end{array}$ & - & - & Var & - & - & Var & - & Var & Var \\
\hline
\end{tabular}

Konfor Bileşeni verilerine bakıldığında; THY’nin Konfor ile İlgili Bileşenlerden koltuklar arası mesafe, koltuk konforu, ek ücretli ikramlar, kabin görevlilerinin sayısı ve uçakta satış bilgilerine web sayfasında yer vermediği; yine konfor ile ilgili bileşenlerden sinıflandırma-economy/comfort/business, özel yolcu hizmetleri, ücretsiz tercihli koltuk seçimi, ücretli tercihli koltuk seçimi, kabin içi hizmet, ücretsiz yemek servisi, ikram çeşitliliği, müşteriye özel yemek çeşitleri ve Uçak içi eğlence hizmetleri bilgilerine ise yer verdiği;

Pegasus'un Konfor ile İlgili Bileşenlerden sınıflandırma-economy/comfort/ business, koltuk konforu, ücretsiz tercihli koltuk seçimi, kabin içi hizmet, ücretsiz yemek servisi, kabin görevlilerinin sayısı, uçak içi eğlence hizmetleri, uçakta satış bilgilerine web sayfasında yer vermediği; özel yolcu hizmetleri, koltuklar arası 
mesafe, ücretli tercihli koltuk seçimi, ikram çeşitliliği, müşteriye özel yemek çeşitleri ve ek ücretli ikramlar bilgilerine yer verdiği;

Güneş (Sun) Ekspres'in Konfor ile İlgili Bileşenlerden sınıflandırma-economy/ comfort/business, koltuk konforu, ücretsiz tercihli koltuk seçimi, kabin içi hizmet, ücretsiz yemek servisi, ikram çeşitliliği, kabin görevlilerinin sayısı bilgilerine web sayfasında yer vermediği; özel yolcu hizmetleri, koltuklar arası mesafe, ücretli tercihli koltuk seçimi, müşteriye özel yemek çeşitleri, ek ücretli ikramlar, uçak içi eğlence hizmetleri ve uçakta satı̧̧ bilgilerine yer verdiği;

Onur Air'in Konfor ile İlgili Bileşenlerden sınıflandırma-economy/comfort/ business, koltuklar arası mesafe, koltuk konforu, ücretsiz tercihli koltuk seçimi, kabin içi hizmet, ücretsiz yemek servisi, ikram çeşitliliği, müşteriye özel yemek çeşitleri, kabin görevlilerinin sayısı, uçak içi eğlence hizmetleri ve uçakta satış bilgilerine web sayfasında yer vermediği; özel yolcu hizmetleri, ücretli tercihli koltuk seçimi ve ek ücretli ikramlar bilgilerine yer verdiği;

Atlasjet' in Konfor ile İlgili Bileşenlerden koltuk konforu, ücretsiz tercihli koltuk seçimi, ücretli tercihli koltuk seçimi, ikram çeşitliliği, kabin görevlilerinin sayısı, uçak içi eğlence hizmetleri ve uçakta satış bilgilerine web sayfasında yer vermediği; diğer konfor bileşenlerine yer verdiği;

Hürkuş’un Konfor ile İlgili Bileşenlerden ücretli tercihli koltuk seçimi, müşteriye özel yemek çeşitleri ve uçakta satış bilgilerine web sayfasında yer verdiği, diğer bilgilere yer vermediği;

İzair'in Konfor ile İlgili Bileșenlerden kendi web sayfasında hiç birine yer vermediği, Pegasus sayfasına yönlendirdiği;

Tailwind'in kurumsal web sitesinde Konfor ile İlgili Bileşenlerden özel yolcu hizmetleri, müşteriye özel yemek çeşitleri, ek ücretli ikramlar ve uçakta satış bilgilerine web sayfasında yer verdiği;

Turistik Hava Taşımacılık'ın Konfor ile İlgili Bileşenlerden özel yolcu hizmetleri, ücretli tercihli koltuk seçimi, ek ücretli ikramlar, uçakta satış bilgilerine web sayfasında yer verdiği görülmektedir.

$\mathrm{Bu}$ veriler 1şığında, THY ve Atlasjet'in Economy/Comfort/Business olarak sınıflandırmaya gitmesi, yine THY'nin ücretsiz koltuk ve yemek seçeneği sunması hizmet anlayışlarında farklılık yaratmaktadır.

\subsubsection{Hizmetlere Erişim Kolaylığı ve Rahatlığı Bileşeni Analizi}

Hizmet bileşenlerinden hizmetlere erişim kolaylığı ve rahatlığı bileşeni rezervasyon ve biletleme kolaylığı (online bilet-online rezervasyon-online check-in), rezervasyon ve biletleme hızlılığ 1 ve doğruluğu bilgisi, ek hizmetler (otel, kiralık araç vb.), biletlemedeki güvenlik önlemleri, canlı destek, sık uçan yolcu programları, zamanında performans, sorun çözümü ile ilgili bilgi (uçuş iptali, bagaj kaybı vb.), bagaj aksaklık bildirimi, bagaj tesliminde hızlılık ve doğruluk, aşırı kilo bagajına uygulanan miktar verilerinden oluşmaktadır. Havayolu işletmeleri bu veriler doğrultusunda incelendiğinde aşağıdaki tablo (Tablo 5) ortaya çıkmaktadır.

Tablo 5: Hava yolu işletmelerinin hizmetlere erişim kolaylığı ve rahatlığı bileşeni verileri

\begin{tabular}{|c|c|c|c|c|c|c|c|c|c|}
\hline & $\bar{E}$ & 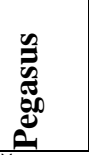 & 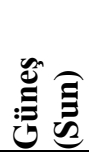 & $\begin{array}{l}\vdots \\
\vdots \\
\vdots\end{array}$ & 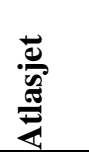 & 恣 & . & : & 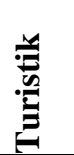 \\
\hline \multicolumn{10}{|c|}{ HIZMETLERE ERISSSIM KOLAYLIĞI VE RAHATLIĞI } \\
\hline $\begin{array}{l}\text { Rezervasyon ve biletleme kolaylığ } 1 \\
\text { Online Bilet-Online rezervasyon-Online Check- } \\
\text { in }\end{array}$ & Var & Var & Var & Var & Var & - & Var & - & Var \\
\hline $\begin{array}{l}\text { Rezervasyon ve biletleme hızlılığ } 1 \text { ve doğruluğu } \\
\text { bilgisi }\end{array}$ & Var & Var & Var & - & - & - & - & - & - \\
\hline Ek Hizmetler (Otel, Kiralık Araç vb.) & Var & Var & Var & Var & Var & - & Var & - & Var \\
\hline Biletlemedeki güvenlik önlemleri & Var & Var & Var & Var & Var & - & - & - & - \\
\hline Canlı Destek & 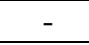 & - & Var & - & - & - & - & - & - \\
\hline Sik uçan yolcu programları & Var & Var & Var & Var & Var & - & - & - & - \\
\hline Zamanında performans & - & Var & - & - & - & - & - & - & - \\
\hline $\begin{array}{l}\text { Sorun çözümü ile ilgili bilgi (uçuş iptali, bagaj } \\
\text { kaybı vb.) }\end{array}$ & Var & Var & Var & Var & Var & - & - & Var & Var \\
\hline Bagaj Aksaklık Bildirimi & Var & Var & Var & - & - & - & - & - & - \\
\hline Bagaj tesliminde hızlılık ve doğruluk & Var & Var & Var & - & Var & - & - & - & - \\
\hline Aşırı kilo bagajına uygulanan miktar & Var & Var & Var & Var & Var & - & - & - & Var \\
\hline
\end{tabular}


Hizmetlere Erişim Kolaylığı ve Rahatlığı Bileşeni verilerine bakıldığında; THY'nin Hizmetlere Erişim Kolaylığı ve Rahatlığı Bileşenlerinden canlı destek ve zamanında performans bilgilerine web sayfasında yer vermediği; rezervasyon ve biletleme kolaylığı, rezervasyon ve biletleme hızlılığ 1 ve doğruluğu bilgisi, ek hizmetler, biletlemedeki güvenlik önlemleri, sık uçan yolcu programları, sorun çözümü ile ilgili bilgi, bagaj aksaklık bildirimi, bagaj tesliminde hızlılık ve doğruluk ile aşırı kilo bagajına uygulanan miktar bilgilerine ise yer verdiği;

Pegasus'un Hizmetlere Erişim Kolaylığı ve Rahatlı̆̆ Bileşenlerinden canlı destek bilgisine web sayfasında yer vermediği; rezervasyon ve biletleme kolaylığı, rezervasyon ve biletleme hızlılığı ve doğruluğu bilgisi, ek hizmetler, biletlemedeki güvenlik önlemleri, sık uçan yolcu programları, zamanında performans, sorun çözümü ile ilgili bilgi, bagaj aksaklık bildirimi, bagaj tesliminde hızlılık ve doğruluk ile aşırı kilo bagajına uygulanan miktar bilgilerine ise yer verdiği;

Güneş (Sun) Ekspres'in Hizmetlere Erişim Kolaylığı ve Rahatlığı Bileşenlerinden zamanında performans bilgisine web sayfasında yer vermediği; rezervasyon ve biletleme kolaylığı, rezervasyon ve biletleme hızlılığı ve doğruluğu bilgisi, ek hizmetler, biletlemedeki güvenlik önlemleri, canlı destek, sık uçan yolcu programları, sorun çözümü ile ilgili bilgi, bagaj aksaklık bildirimi, bagaj tesliminde hızlılık ve doğruluk ile aşırı kilo bagajına uygulanan miktar bilgilerine ise yer verdiği;

Onur Air' in Hizmetlere Erişim Kolaylığı ve Rahatlığı Bileşenlerinden rezervasyon ve biletleme hızlılığı ve doğruluğu bilgisi, canlı destek, zamanında performans, bagaj aksaklık bildirimi, bagaj tesliminde hızlılık ve doğruluk bilgisine web sayfasında yer vermediği; rezervasyon ve biletleme kolaylığı, ek hizmetler, biletlemedeki güvenlik önlemleri, sık uçan yolcu programları, sorun çözümü ile ilgili bilgi ile aşırı kilo bagajına uygulanan miktar bilgilerine ise yer verdiği;

Atlasjet'in Hizmetlere Erişim Kolaylığı ve Rahatlığı Bileşenlerinden rezervasyon ve biletleme hızlılığı ve doğruluğu bilgisi, canlı destek, zamanında performans ve bagaj aksaklık bildirimi bilgilerine web sayfasında yer vermediği; rezervasyon ve biletleme kolaylığı, ek hizmetler, biletlemedeki güvenlik önlemleri, sık uçan yolcu programları, sorun çözümü ile ilgili bilgi, bagaj tesliminde hızlılık ve doğruluk ile aşırı kilo bagajına uygulanan miktar bilgilerine ise yer verdiği;

Hürkuş’un Hizmetlere Erişim Kolaylığı ve Rahatlığı Bileşenlerinden hiç birine yer vermediği;

İzair'in Hizmetlere Erişim Kolaylığı ve Rahatlığı Bileşenlerinden rezervasyon ve biletleme hızlılığı ve ek hizmetler bilgilerine web sayfasında yer verdiği;

Tailwind'in Hizmetlere Erişim Kolaylığı ve Rahatlığı Bileşenlerinden rezervasyon ve biletleme hızlılığı, ek hizmetler, sorun çözümü ile ilgili bilgi ve aşırı kilo bagajına uygulanan miktar bilgilerine web sayfasında yer verdiği;

Turistik Hava Taşımacılık'ın Hizmetlere Erişim Kolaylığı ve Rahatlı̆̆ı Bileşenlerinden rezervasyon ve biletleme kolaylığı, ek hizmetler, sorun çözümü ile ilgili bilgi ve aşırı kilo bagajına uygulanan miktar bilgilerine web sayfasında yer verdiği görülmektedir.

Bu veriler sonucunda, işletmelerin hizmetlere erişim kolaylığı ve rahatlığı bileşenini oluşturan hizmetlerde, birbirine yakınlık gösterdiği, ancak Pegasus'un diğerlerinden farklı olarak "zamanında performans" ile Güneş (Sun) Ekspres'in “canlı destek” hizmetiyle farklılık oluşturduğu ortaya çıkmaktadır.

\subsection{5. İmaj Bileșeni Analizi}

Hizmet bileşenlerinden imaj bileşeni görsel kimlik, kurumsal sosyal sorumluluklar, kurumsal iletişim, sponsorluklar, halkla ilişkiler, kurumsal reklamcılık ve hizmet kalitesi ile ilgili verilerinden oluşmaktadır. Havayolu işletmeleri bu veriler doğrultusunda incelendiğinde aşağıdaki tablo (Tablo 6) ortaya çıkmaktadır. 
Tablo 6: Hava yolu işletmelerinin imaj bileşeni verileri

\begin{tabular}{|c|c|c|c|c|c|c|c|c|c|}
\hline & $\bar{\Xi}$ & 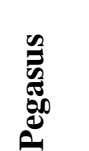 & 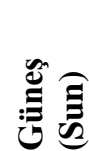 & $\begin{array}{l}\vdots \\
\vdots \\
\vdots\end{array}$ & 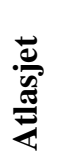 & 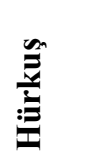 & 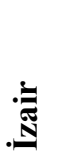 & & 节 \\
\hline \multicolumn{10}{|l|}{ İMAJLA İLGİLİ BİLEȘENLER } \\
\hline Görsel Kimlik & Var & Var & - & Var & Var & - & - & Var & Var \\
\hline Kurumsal Sosyal Sorumluluklar & - & - & - & - & - & - & - & - & - \\
\hline Kurumsal İletişim & Var & Var & Var & Var & Var & Var & - & Var & Var \\
\hline Sponsorluklar & Var & Var & Var & - & Var & - & - & - & - \\
\hline Halkla İlişkiler & Var & Var & Var & Var & Var & - & Var & Var & Var \\
\hline Kurumsal reklamcilik & Var & Var & - & Var & Var & - & - & - & - \\
\hline Hizmet Kalitesi İle İlgili Bilgi & Var & Var & - & Var & Var & Var & Var & - & - \\
\hline
\end{tabular}

İmaj Bileşeni verilerine bakıldığında; THY'nin İmajla İlgili Bileşenlerden sadece kurumsal sosyal sorumluluğa web sayfasında yer vermediği; görsel kimlik, kurumsal iletişim, sponsorluklar, halkla ilişkiler, kurumsal reklamc1lı ve hizmet kalitesi ile ilgili bilgilere ise yer verdiği;

Pegasus'un İmajla İlgili Bileșenlerden sadece kurumsal sosyal sorumluluğa web sayfasında yer vermediği; görsel kimlik, kurumsal iletişim, sponsorluklar, halkla ilişkiler, kurumsal reklamcılık ve hizmet kalitesi ile ilgili bilgilere ise yer verdiği;

Güneș (Sun) Ekspres'in İmajla İlgili Bileșenlerden görsel kimlik, kurumsal sosyal sorumluluk, kurumsal reklamcılık ve hizmet kalitesine web sayfasında yer vermediği; kurumsal iletişim, sponsorluklar, halkla ilişkiler ile ilgili bilgilere ise yer verdiği;

Onur Air'in İmajla İlgili Bileșenlerden kurumsal sosyal sorumluluk ve sponsorluklara web sayfasında yer vermediği; görsel kimlik, kurumsal iletişim, halkla ilişkiler, kurumsal reklamcılık ve hizmet kalitesi ile ilgili bilgilere ise yer verdiği;

Atlasjet'in İmajla İlgili Bileşenlerden kurumsal sosyal sorumluluk çalışmalarına web sayfasında yer vermediği; görsel kimlik, kurumsal iletişim, halkla ilişkiler, sponsorluklar, kurumsal reklamcılık ve hizmet kalitesi ile ilgili bilgilere ise yer verdiği;

Hürkuş’un İmajla İlgili Bileşenlerden görsel kimlik, kurumsal sosyal sorumluluk halkla ilişkiler, sponsorluklar ve kurumsal reklamcılık çalışmalarına web sayfasında yer vermediği; kurumsal iletişim ve hizmet kalitesi ile ilgili bilgilere ise yer verdiği;

İzair'in İmajla İlgili Bileşenlerden görsel kimlik, kurumsal sosyal sorumluluk, kurumsal iletişim, sponsorluklar ve kurumsal reklamcılık çalışmalarına web sayfasında yer vermediği; halkla ilişkiler ve hizmet kalitesi ile ilgili bilgilere ise yer verdiği;

Tailwind'in İmajla İlgili Bileșenlerden kurumsal sosyal sorumluluk, sponsorluklar, kurumsal reklamc1lk ve hizmet kalitesi ile ilgili bilgilere web sayfasında yer vermediği; görsel kimlik, kurumsal iletişim ve halkla ilişkiler çalışmalarına ise yer verdiğii;

Turistik Hava Taşımacılık’ın İmajla İlgili Bileşenlerden görsel kimlik, kurumsal iletişim ve halkla ilişkiler bilgilerine yer verdiği görülmektedir.

Ortaya çıkan bu veriler THY, Pegasus ve Atlasjet işletmelerinin imaj bileşenlerine daha fazla yer verdiklerini göstermektedir.

Hava yolu işletmelerinin hizmet bileşenlerini oluşsturan bu beş başlık altındaki verilere karşılaştırmalı olarak bakıldı̆̆ında ise;

Türkiye'deki hava yolu işletmeciliğinde açık ara lider konumda bulunan THY'nin, diğer işletmelere göre kurumsal web sayfasında hizmet bileşenlerinin büyük çoğunluğuna yer verdiği;

Pegasus'un, THY'ye göre hizmet bileşenlerini oluşturan; "fiyat+hizmet-normal bilet", "yaygın uçuş ağ 1 bilgisi", "sınıflandırma", "ücretsiz tercihli koltuk seçimi", "kabin içi hizmet", "ücretsiz yemek servisi" ve "uçak içi eğlence hizmetleri” gibi özelliklere yer vermediği; bunlara karşılık "düşük fiyat-ucuz bilet", "uçuş paketleri", "koltuklar arası mesafe", "ek ücretli ikramlar" ve "zamanında performans" özelliklerine yer verdiği;

Güneş (Sun) Ekspres'in, Pegasus'a göre hizmet bileşenlerini oluşturan; "yeterli uçuş sıklığı", "ikram çeşitliliği”, "zamanında performans", "görsel kimlik", "kurumsal reklamcilık" ve "hizmet kalitesi ile ilgili bilgi" gibi özelliklere yer vermediği; bunlara karş1lık "uçak içi eğlence hizmetleri”, "uçakta satış" ve "canlı destek" özelliklerine yer verdiği; 
Onur Air'in, Pegasus ve Güneș (Sun) Ekspres’e göre; "koltuklar arası mesafe", "müșteriye özel yemek çeşitleri”, "uçak içi eğlence hizmetleri", "uçakta satış", "rezervasyon ve biletleme hızlılığı ve doğruluğu bilgisi", "canlı destek", "bagaj aksaklık bildirimi", "bagaj tesliminde hızlılık ve doğruluk" ve "sponsorluklar" gibi özelliklere yer vermediği; "görsel kimlik", "kurumsal reklamcılık" ve "hizmet kalitesi ile ilgili bilgi" özelliklerine ise onlardan farklı olarak yer verdiği;

Atlasjet'in, Güneş (Sun) Ekspres ve Onurair'e göre; "ücretli tercihli koltuk seçimi” özelliğine yer vermediği; "fiyat+hizmet-normal bilet", "sınıflandarma", "koltuklar arası mesafe", "kabin içi hizmet", "ücretsiz yemek servisi”, "müşteriye özel yemek çeşitleri”, "bagaj tesliminde hızlılık ve doğruluk" ile "sponsorluklar" gibi özelliklere onlardan farklı olarak yer verdiği;

Hürkuş, İzair ve Tailwind'in diğer işletmelere göre, hizmet bileşenlerinin çok büyük kesimine yer vermediği; ancak hepsinin tek olarak "filo tanıtımı"na yer verdiği;

Turistik Hava Taşımacılık firmasının ise, kurumsal web sayfasında, Hürkuş, İzair ve Tailwind'a göre; daha çok hizmet bileşenine onlardan farklı olarak yer verdiği görülmektedir.

\section{SONUÇ}

Dünya havacılık sektöründe olduğu gibi ülkemiz havacılık sektöründe de yaşanan yoğun rekabet, sektördeki firmaları kullandıkları teknoloji, tarife ve hizmetlere erişme konusunda tek tipleşmeye; hizmet anlayışları konusunda ise farklılaşmaya doğru itmektedir. Bu nedenle, günümüzdeki hava yolu işletmelerinin belki de en fazla üzerinde durdukları ve tüm tanıtım çalışmalarında özellikle vurguladıkları konu "hizmet anlayışı farklılı̆̆ı" olmaktadır. Hizmet anlayışlarının işletmelerin resmi web sayfalarına nasıl yansıdığına, Türkiye'deki hava yolu işletmelerinin resmi web sayfaları analiz edilerek ulaşılmaya çalışıldığında ise, şu sonuçlara ulaşılmaktadır:

1-THY'nin yüksek hizmet kalitesine, geniş uçuş ağına, güçlü filosuna ve güvenliğe yönelik hizmet anlayışını web sayfasında yansıtıp yansıtmadığını ortaya koymak açısından, hizmet bileşenleri çerçevesinde analiz edildiğinde; "Uçak bileti fiyatları THY kalitesiyle" sloganıyla "kaliteye" vurgu yaptı̆̆ı, web sayfasında tüm hizmet bileşenlerine büyük çoğunlukla yer verdiği, özellikle "tarife", "konfor", "hizmetlere erişim kolaylığı ve rahatlı̆̆ı" ile "imaj" bileşenlerine daha fazla yer verdiği görülmektedir.

2- Pegasus'un hizmet anlayışında ucuz bilet ve zamanında performans yer almaktadır. "Ucuz uçak bileti demek özgürlük demek" sloganında "uçak biletinde ucuzluğa" yapılan vurgu, Pegasus'un hizmet anlayışına yansıdığı kurumsal web sayfasındaki hizmet bileşenlerinde kendisini göstermektedir. Pegasus kurumsal web sayfasında ücretlerle ilgili bilgilere önemli ölçüde yer verirken, "zamanında performans" bileşenini uygulayan tek işletme olduğu görülmektedir. Bunun yanında diğer hizmet bileşenlerine de büyük çoğunlukla yer vermekte, ancak bu hizmetler için ek ücret istemektedir.

3- "Ucuz uçak bileti" sloganıyla "ucuzluğa" vurgu yapan Güneş (Sun) Ekspres'in hizmet anlayışının kurumsal web sayfasına yansıyıp yansımadığına bakıldığında; firmanın kurumsal web sayfasında hizmet bileşenlerinden "ücretler" ve "hizmetlere erişim kolaylığı ve rahatlı̆̆ı" bileşenlerine en fazla yer verdiği, diğer ucuzluğa vurgu yapan işletmelerden farklı olarak canlı destek ve uçak içi eğlence bileşenine yer verdiği sonucu da görülmektedir.

4-"En uygun fiyata uçak bileti" sloganıyla "ucuz bilet" vurgusu yapan ve hizmet anlayışını da buna göre şekillendiren Onur Air, bu amaçla kurumsal web sayfasında hizmet bileşenlerinden en fazla "ücretler", "tarife" ve "imaj" konusunda bilgiler yayınlamakta, "konfor" ile ilgili bileşenlere ek ücret istemekte ve daha az vurgulamaktadır.

5- Kurumsal sloganında "En uygun yurtiçi, yurtdışı uçak bileti” sloganıyla "ucuz uçak bileti" vurgusu yapan Atlasjet'in kurumsal web sayfası hizmet bileşenleri doğrultusunda analiz edildiğinde, hizmet bileşenlerinden en fazla "ücretler" ve "imaj" bileşenlerine önem verdiği görülmektedir. Diğer "düşük fiyatucuz bilet" anlayışına sahip işletmelerden ayrı olarak konfor bileşenine daha fazla yer verdiği, koltuk ve yemek seçiminde ek ücret istemediği görülmektedir.

6- Hürkuş, İzair ve Tailwind'in kurumsal web siteleri hizmet bileşenleri doğrultusunda analiz edildiğinde, hizmet bileşenlerinin çok büyük kesimine yer vermeyip çok az bileşene yer verdikleri görülmektedir. Hepsinin web sitesinde yer verdiği tek özellik ise "filo tanıtımı" olarak ortaya çıkmaktadır.

7- Kurumsal sloganı "Ucuz uçak bileti" olan Turistik Hava Taşımacılığın "ucuzluk" anlayışının kurumsal web sitesine yansıyıp yansımadığına bakıldığında ise, bu durumun kurumsal web sayfasına yansıdığı görülmektedir. Turistik Hava Taşımacılık, kurumsal web sayfasından en fazla "tarife ile ilgili hizmet bileşenlerine" yer vermekte; dolayısı ile ucuzluğun yanında kalite, konfor gibi bileşenlerin aranmaması gerektiğine vurgu yapan bir web sayfasına sahiptir. 
Sonuç olarak; Türkiye'de hava yolu taşımacılığı yapan işletmeler hizmet anlayışlarını yeni iletişim araçlarından kurumsal web sayfalarında, çeşitli derecelerde olmak kaydıyla, başarılı şekilde yansıtmaktadırlar. Ayrıca hava yolu taşımacılığı faaliyetinde bulunan işletmelerin büyüklüğü (filo ve taşıma kapasitesi) arttıkça, kurumsal web sayfalarında hizmet bileşenleri ile ilgili bilgiler artmakta, işletmeler küçüldükçe de hizmet bileşenleri ile ilgili bilgiler azalmaktadır denilebilir. 


\section{KAYNAKÇA}

Canöz, Nilüfer (2015). Hizmet Sektöründe Kurumsal İmaj Algısı, Palet Yayınları, Konya.

Doganis, Rigas (1991). Flying Off Course, The Economics of International Airlines, Routledge, London.

Gerede, Ender (2015). Uluslararası Havayolu Taşımacılığında Liberalleşme Süreci, Ed: Ender Gerede, Havayolu Taşımacılığı ve Ekonomik Düzenlemeler Teori ve Türkiye Uygulaması, SGHM Yayını, s.1-46, Ankara.

http://www.tuik.gov.tr/PreTablo.do?alt id=1051, Erişim Tarihi:15.06.2017

http://investor.turkishairlines.com/tr/mali-veriler/yillik-raporlar/1/2016, Erişim Tarihi:16.08.2017

https://www.tailwind.com.tr, Erişim Tarihi:16.08.2017

https://www.freebirdairlines.com/tr/ Erişim Tarihi:16.08.2017

https://www.flypgs.com/, Erişim Tarihi:17.08.2017

http://www.izair.com.tr/tr/anasayfa/, Erişim Tarihi:17.08.2017

https://www.sunexpress.com/tr/, Erişim Tarihi:17.08.2017

https://www.atlasglb.com/, Erişim Tarihi:18.08.2017

https://p.turkishairlines.com/, Erişim Tarihi:18.08.2017

https://www.corendonairlines.com Erișim Tarihi:18.08.2017

Karasar, Niyazi (2010). Bilimsel Araştırma Yöntemi, Nobel Yayın Dağıtım, Ankara.

Sayımer, İdil (2008). Sanal Ortamda Halkla İlişkiler, Beta Yayınları, İstanbul.

Ste1l, Peter ve Emery, Garry (1997). Corporate İmage and Identity Strategies Designing the Corporate Future, Business\&Professionel Publishing, Warriewood NSW.

Wensveen, John G. (2007). Air Transportation:A Management Perspective, Ashgate Publishing, Burlington.

Xie, Zhou C. and Barnes, Stuart J. (2009). "Web Site Quality In The Uk Airlıne Industry:A Longitudınal Examınation”, Journal of Computer Information Systems, Winter 2008-2009, pp.50-57.

Şengür, Ferhan Kuyucak ve Şengür, Yusuf (2012). "Havayolu İş Modelleri: Kavramsal Bir Analiz", https://www.researchgate.net/profile/Ferhan_Kuyucak_Sengur/publication/309533631_Havayolu_Is_Modelleri_ Kavramsal_Bir_Analiz/links/58aeb4d892851cf7ae85d085/Havayolu-Is-Modelleri-Kavramsal-Bir-Analiz.pdf, Erişim Tarihi:16.08.2017

www.dhmi.gov.tr/getBinaryFile.aspx? Type=9\&dosyaID=691, Erișim Tarihi: 14.06 .2017 